\title{
Customer Loyalty of Nokia Mobiles; an Empirical Study Conducted In Pakistan
}

\author{
Zeeshan Haneef \\ Department of Management Sciences, the Islamia University of Bahawalpur, Pakistan
}

Syed Habib Raza Rizvi

Department of Management Sciences, the Islamia University of Bahawalpur, Pakistan

Hussain Ahmad Madni

Department of Management Sciences, the Islamia University of Bahawalpur, Pakistan

Abdullah Khakwani

Department of Management Sciences, the Islamia University of Bahawalpur, Pakistan

\author{
Muhammad Rizwan (Corresponding author) \\ Lecturer, Department of Management Sciences, \\ The Islamia University of Bahawalpur, Pakistan \\ E-mail: rizwan.arshad@iub.edu.pk
}

Doi:10.5296/ jsr.v5i1.6573

URL: http://dx.doi.org/10.5296/ jsr.v5i1.6573

\begin{abstract}
Customer loyalty is a psychological motive which today's managers are considerate about. Today in the world of competition, customer loyalty is the basic thing for the company's survival. In this research paper, we study the variables which directly or indirectly affect the loyalty of the customer and these variables are the customer satisfaction, customer trust, and vendor communication, perceived value, perceived quality, relational benefits, and brand credibility. For this purpose, we conducted a self-administrated survey to collect the data. Data is collected from 150 respondents, and the study employed statistical analyses, such as reliability
\end{abstract}


analysis and regression analysis. The results of the study show the positive significant relation with all variables except perceived value because of unsystematic errors. The other reason of this relation is that we do not target one product of Nokia mobiles specifically.

Keywords: Customer Loyalty, Customer needs, Market, Pakistan

\section{Introduction}

Customer loyalty is customer intention to reuse something based on his experience and expectancy in the past. Customer loyalty is a company's most enduring assets. By creating and maintaining customer loyalty, a company develops a long-term, mutually beneficial relationship with the customers.

Creating loyal customers has become more important due to significant increase in competitive and concentrated markets. The world has moved gradually from satisfying customers to determining ways to a leap forward into making them loyal and the most important part of the current businesses. Today, world has become a place of competition, survival of the companies has become very difficult, research suggests that building long term relations with the customers is very important factor for managers. There are a number of factors which affect the customer loyalty. But in our research paper, we studied the variables which can affect the customer loyalty and these are the customer satisfaction, customer trust, vendor communication, brand credibility, perceived quality, and relational benefits.

Customer satisfaction is the inner feeling of the customer. If product meets the customer's expectations then it makes the customer satisfied. If the customer is satisfied then he will be loyal with the company. Customer trust is the true promise of the vendor or the seller with the customer. If the seller or vendor did all of his work according to his promise then it creates the trust of the customer which is the most important indicator for the customer loyal. Business deal occurs when two parities are trust worthy for each other. Perceived value of the customer is the wish or the desire of the customer about the product for which he sacrifices his monetary value. Vendor communication with the customer helps the customer to be loyal with the organization e.g. in e-commerce the communication is one of the best indicator for the customer loyalty. If the vendor responds quickly to the customer then it will create the positive thinking of the customers about the product e.g. handling the complaints of the customer quickly and save their time.

Perceived quality is the perception of the customers about the ability of the product to meet their needs and desires. If we discuss basically the quality, it is the ability of the product to fulfill the expectations of the customer. It is also an important tool to give satisfaction to the customer about the product. If the customer uses the product and considers that the product has ability to meet his demands then he will become satisfied with that particular product and this satisfaction will force the customer to use the product again and again.

Relational benefits are the associated benefits with the product, e.g. social benefits of the 
product, customization benefits, economic benefits and symbolic benefits. We check these benefits most of the time while purchasing the product. We use environment friendly product because we are conscious about the environment. Sometimes, we only buy the product because it is cheaper than others. Firms can maintain their customer loyalty through the customer satisfaction and creating trust of the customer. Firm can increase the customer satisfaction through increasing benefits which are associated with the product. Loyalty has been a primary concern in marketing planning for different reasons including global competition, market saturation, technological development, and customer awareness. Price is not just a function to retain our customers but it is the quality of product and services which maintain long term relations of the customers with the company. Thus, it is important to increase and retain loyal customers, which may serve as a major factor in long-term success of corporations. Corporations attempt to absorb and satisfy customers and build a long-term relationship through creating loyalty among them (Akhter et. al.; 2011)

The purpose of this research paper is to identify that how can we create the customer loyalty and this research paper gives us the way by which we can assess the major factors which affect the customer loyalty. If we take a deep measure or analysis of this research paper, we will understand that what are the variables which have influence on the customer loyalty? Loyalty of the customer is very important for any organization because it is the basic reason of the success of the companies. Companies always try to increase their customer loyalty, but they have confusion that what are the exact factors by which we can win the repurchase behavior of the customer and main object of our research is to give them the fundamentals of the loyalty.

\section{Literature review}

\section{Customer loyalty}

Loyalty is important concentration of customers towards sticking with or switching from their suppliers. Customer basically decides that he will purchase the same product from the same organization or not. Loyalty can never be purchased by the companies, it is the decision of the customer that he will remain with the same organization forever or switch to another one.

But we can force the customer to purchase again and again just with the help of benefits, incentives and packages. The retention is subject to the product attributes, pecuniary switching costs, prices and internal loyalty is through customer care. Loyalty is internal feeling of the customer towards any product or organization; it can only be changed if we change the customer's judgment about the product. Customer loyalty can also be increased by the company through the proper incentive plans and strategies.

Loyalty can never be ensured. If the customer is satisfied with the company then we will always try to maintain his relations with the firm and he will be loyal with the company. When the customer is loyal with the company then company reduces its costs e.g. costs of setting customers, costs of attracting prospective customers through advertisements and aggressive marketing promotion; costs of personal selling and advertisement. So when firms create the loyalty of the customer then it does not only increase the profit of the company 
through developing the customer purchase intension but also minimize the costs which are mention above. So customer loyalty is the main factor for the companies' success in long run. (Chang, Yao and Ying, 2009).

Reichland (1996) has described in his study that if we increase the customer loyalty on minimal level then its result will be high increase in the profit. The concept of customer repurchasing decision, loyalty, and defection is getting a lot of attention in many industries (Matt Hasan, 2001). The market is divided into different areas and these areas are further divided into the groups and the people of groups have similar choices within the groups, not it's between (Stewart, 1998). If companies want to do marketing base on their loyalty then firstly, they have to recognize who are their loyal customers and to which customer they have to target, it helps the companies to focus on their main customer rather than consumers which deal in the consumer good product (Fox and Poje, 2002).

So, customer loyalty is an important factor to expand the business because engaging one customer with the company means attracting other customers and losing one customer means losing other customers.

\section{Customer trust:}

Trust means anything or any promise you are doing with someone then you fulfill that promise with that particular person. Trust has been studied extensively in literature. Trust has been defined as one party believing that the other party will fulfill his or her needs. Trust is the internal feeling of the customer that companies fulfill his needs through its services and product (Anderson\&Weitz, 1989).

If we see the broader term then we can say that trust is like a confidence of one person or party about the honesty and reliability of other person or party (Morgan \& Hunt, 1994).Business transactions between two sides can be taken when one party has completed confidence on the other party. Trust cannot be admitted easily by other side/business partner; it must be built from the beginning and can be proved. Trust is considered as the medium in the business transactions between two parties, so that we can measure the satisfaction of the customer which he is expected from the firm (Yousafzai, S.Y., Pallister, J.G., and Foxall, G.R.(2003), Specifically, trust reduces ambiguity in an environment where customers feels susceptible because they know that they can rely on the trusted organization (Aydin \& Ozer 2005: 146).

Based on some definitions above, it can be stated that trust is a form of one side's trust to other side in performing transactions based on a confidence that his trusted person will fulfill all of his responsibility as expected. Trust is the major thing by which we can create the loyalty of the customer.

Al Hawari (2011) suggested customer trust as an important factor that increases customer commitment. (Ndubisi 2007) found that trust is very important factor that builds loyalty and there is a significant and positive relationship between trust and loyalty. Building customer 
confidence and providing quality service leads the organization towards enhancing customer trust and at the end, trust makes the customer loyal. Trust is a type of feeling which give strong positive image in the mind of the customer that the organization giving him that particular thing which he expects from the company (Deutchi, 1958). Actually, trust is a relation who attaches the consumers with the company. Trust also involves between the workers of an organization.

\section{H1: Positive effect of customer trust on the customer loyalty}

\section{Customer satisfaction}

Customer satisfaction is the attitude of the customer and this attitude can be developed when he uses the product of any company, this usage gives him experience about the product and on the basis of that experience he evaluates his satisfaction (Fornell, 1992). It is a reflection of being content with such a product or a service.

Satisfaction is the evaluation of the experience of interacting with vendor up to the present time, and it also helps the customer to predict the future from his past experience (Crosby et al., 1990).Satisfaction is one of the antecedents of customer loyalty.

Customer satisfaction is a term which is used in marketing, satisfaction of the customer gives the measure that how our product meet the requirements of the customers. If customer satisfaction is high with the supplier then it will create a long-term commitment with the organization (Ganesan,1994; Geyskens et al., 1999). So, satisfaction directs the customer towards loyalty. Now question is that how this occurs and to what extent it is not as easily answered. Simple answer is that when customer feels satisfaction from one supplier again and again, he will try to maintain this relationship with the supplier because it is also difficult and may be costly for the customer to switch. This process has also been described to be occurred in phases, loyalty of the customer which is built after some period of time from satisfaction to strong commitment (Oliver, 1997).

Mayer et al. (1995) defines trust as "the willingness of a party to be vulnerable with the actions of another party based on the expectation that the other will perform the particular action important for trust or, irrespective of the ability to monitor or control that other party". Service providers, in some cases, may not be able to retain their satisfied customers (Heskett et al., 1994; Schneider and Bowen, 1999) because the customer satisfaction itself alone cannot ensure long term commitment of the customer to any service provider. Instead, the service providers should think to the other factors beyond customer satisfaction, such as customer trust, to retain their customers (Hart and Johnson, 1999). This argument is supported by Morgan and Hunt (1994). Morgan and Hunt(1994) assert that the target of the firms is to develop customer trust beyond customer satisfaction to retain their customers in a long term period. In other words, customer trust is likely to be a strong driver of customer retention (Ranaweera and Prabhu, 2003).

\section{H2: customer satisfaction has positive influence on the customer trust}




\section{H3: customer satisfaction positively affects the customer loyalty}

\section{Perceived value}

It is necessary in the competitive market that the supplier must understand and know that what is their value in the minds of their customer? (e.g. Slater \& Narver, 2000;Vargo \& Lusch, 2004; Woodruff, 1997). Some researches show that knowledge about the value is not enough, companies should have the capability to anticipate the value of their customer because in the world of competition customer's value changes day by day(Flint, Woodruff, \& Gardial, 2002). Implying the need for such a capability, market-orientation research calls for marketers to partly focus on varying customer needs(Jaworski \& Kohli, 1993; Matsuno \&Mentzer, 2000; Siguaw, Simpson, \&Baker, 1998). While the former refers to customers' feelings in response to a particular product or service encounter, the later describes satisfaction that accumulates across a series of encounters and is a more fundamental indicator of a supplier's overall performance through time (Bitner \& Hubbert, 1994; Rust \& Oliver, 1994). Suppliers' anticipation of what customers will value is an ongoing process, and as such, we focus on satisfaction at a global level in our investigation.

The conclusion is that some customers might come to expect suppliers to anticipate their needs and desires (even if they themselves cannot). Linked to customer value research, customer satisfaction research has a strong history of measuring expectations as a comparison standard in the disconfirmation paradigm (Oliver, 1980; Yi, 1990).

Customers' expectations can be formed based on several factors (Zeithaml, Berry, \& Parasuraman, 1993) and can sometimes be referred to as "desires." Spreng, MacKenzie, and Olshavski (1996). Desire breaks out as a distinct comparison standard construct to reflect what customers want. We know that those firms that best meet customers' current desires usually have more satisfied and loyal customers. Although marketers are advised to look to their customers' futures for product and service improvement and development (Flint, 2004; Morrison \& Schmid, 1994), we have not yet known if doing so has an impact on customer satisfaction or loyalty.

\section{H4: perceived value positively influence the customer satisfaction}

\section{Relation benefit}

Relational benefits are those benefits which engage the customer with the company and make cause of the customer satisfaction. Relationship marketing, which focuses on approaches to building, developing and maintaining a successful relational exchange (Gro" nroos, 1994; Morgan and Hunt, 1994), is changing marketing orientation from attracting short-term, discrete transactions to retaining long-lasting, intimate customer relationships.

Czepiel (1990) has suggested that when customer makes longterm relations with the company, he expects some additional benefits as result of its loyalty. These benefits that are interpersonal in nature have been termed relational benefits in the literature, and accrue to those customers who are engaged in continuing relationships with the service provider and its 
personnel (Gwinner et al., 1998; Hennig-Thurau et al., 2002). Relational benefits give the scene of the customer satisfaction.

Gwinner et al. (1998) conducted in-depth interviews and quantitative studies to examine the benefits that customers receive from relational exchanges. Their findings from the qualitative study first reveal four relational benefits in terms of the psychological (Bitner, 1995; Morgan and Hunt, 1994), social (Berry,1995; Price and Arnould, 1999), economic (Peterson, 1995) and customization benefits (Barlow, 1992; Crosby, 1991). Subsequently, they empirically identify a typology of three relational benefits: confidence benefits (psychological), social benefits, and special treatment benefits (economic and customization).

According to Mintzberg (1994), the appropriateness of relational strategy (e.g. relational benefits) is connected to customer perceived value. Additionally, perceived value is regarded as the basic foundation for all marketing activities (Holbrook, 1994) and the customer's overall consideration about products and services (Zeithaml, 1988).

\section{H5: effect of the relational benefits on the customer satisfaction}

\section{H6: relational benefits affect the perceived value}

\section{Brand credibility}

Kotler and Keller (2008) described that brand can be anything, a name, term, sign, symbol, design, or combination of these; it is the brand which recognize the goods and services of the seller and find the difference between one seller and another. Customers and users evaluate identical products and services based on their brands. One way to reach information about brands is past experiences by customers. Customers compare different brands to selected best ones according to their needs and requirements. Kotler and Keller (2008) believed that the decision making process becomes easy with the help of brand and it simplify the life of people. Kotler and Keller (2008) believed that brand also helps to manage the financial record of the firms. Besides, the brand name can be protected through registered trademarks; manufacturing processes can be protected through patents; and packaging can be protected through copyrights and designs. These intellectual property rights ensure that the firm can invest in the brand in a safe manner and reach the benefits of a valuable asset. Following Kotler and Keller's notion, brand can be one of the measures of the level of quality; therefore, it can meet customers' requirements and builds trust that customers will repeat using existing brand. This repeating process of buying refers to loyalty, which is beneficial for firms to stay in competitive market, such as barriers to new entry firms and other rivals.

Sobel (1985) recognized that trust is the first and main factor which forces people to make decisions. When there is lack of trust between the partners then uncertainty increased automatically in the businesses. In Sobel's (1985) view, people trust on others just because of their reliable behavior and it create after some period of time.

\section{H7: Brand credibility effect the customer trust}




\section{Perceived quality}

To create long-lasting customer relationships, relationship marketing, includes promotion activities that attract, develop, maintain, and enhance customer relationships, and has been utilized in a wide variety of industries (Berry, 1995).

Customers care about the relationship as a whole and judge the relationship using past experience, expectations, predictions, goals, and desires (Crosby, Evans,\& Cowles, 1990). Relationship quality has been positively linked to customer loyalty (Hennig-Thurau \& Klee, 1997; Roberts, Varki, \&Brodie, 2003). There is no unified definition of relationship quality (Rauyruen \& Miller, 2007; Robie, Ryan, Schmieder, Parra, \& Smith,1998). Relationship quality has been conceptualized as a construct consisting of several components.

These factors include satisfaction (Crosby et al., 1990; Dwyer \& Oh, 1987), trust (Dwyer\& Oh, 1987; Hennig-Thurau \& Klee, 1997), commitment (Hennig-Thurau \& Klee, 1997), and overall quality (Hennig-Thurau \& Klee,1997) among others. In the prior studies, satisfaction, trust, and commitment are the most examined aspects of relationship quality (Athanasopoulou, 2009; Bejou, Wray, \& Ingram, 1996; Crosbyet al., 1990; De Canniere, De Pelsmacker, \& Geuens, 2009; Lagace,Dahlstrom, \& Gassenheimer, 1991; Rauyruen \&Miller, 2007; Wray,Palmer, \& Bejou, 1994). In this study, we conclude that the quality of the product consists of the customer satisfaction, customer trust, and commitment and these generate the idea of the customer loyalty.

\section{H8: perceived quality positively influence the customer satisfaction}

\section{H9: perceived quality has positive influence on the customer trust}

\section{Vendor communication}

Relationship marketing is defined as the process of establishing and maintaining mutually beneficial long-term relationships among organizations and their customers, employees and stakeholders. This shift to building relationships is offered as a solution to organizations in promoting sustainable relationships in this era of ever-increasing competition (Rensburg \& Cant, 2003:119). Communication between the organizations is very important, all the member of organizations communicate with each other. It is impossible for the firm to perform its function without communication. Van Staden etal., (2002) cite the following advantages of communicating effectively with customers:

- Good customer relationships

- Saving time and money•

More effective decision-making

Communication is believed to directly affect the building of long term relationships with the stakeholders of an organization. It is therefore, necessary to recognize the role of communication in building relationships between the various activities in the organization 
and between the organization and its stakeholders (Ransburg \& Cant, 2003:120). That shows that communication directly affects the customer loyalty.

Vendor communication affects the customer loyalty. Communication, itself does not mean that just handling the customer on the table. It also includes that how companies respond to the customer and how efficiently they are handling their claim and problems.

In a study, Heidarzadeh (2006) found a positive and significant connection among individual service employee's communication with customers `relationships and loyalty. Rezaee (2009) in his study proved that communication among individual employees and customers together influence customers`satisfaction and loyalty. Guenzi \& Pelloni (2004) in their research on health and fitness clubs concluded that customer loyalty only would be affected through close relationships between customers and employees.

\section{H10: Vendor communication directly influence the customer loyalty}

\section{Research methodology}

The current research is descriptive in its nature. Descriptive research can be explained as describing something, some phenomenon or any particular situation. In Descriptive research, we explain the phenomena or situation not any type of interpretation occurs in the descriptive research (creswell.1994). The fist purpose of the descriptive research is verification of the developed hypotheses that reflects the current situation. Further we explain that how we collect data, what are the instruments and measures which we take to get the data from the people, what are the tools which analyze and interpret our data and convert it into necessary information.

\subsection{Sample/Data}

In order to collect data for understanding the situation about loyalty of the customer with Nokia mobiles; a sample of 150 respondents was asked to participate in a self-administered questionnaire. The population for the current research was the users of Nokia mobile in Pakistan. It has ensured that sample member should be the user the Nokia. We select these sample members from the different areas in the Bahawalpur and Lodhran. Two main clusters will target to collect the sample data like university student and working professionals. If we see our research so it is based more on educated people.

\subsection{Instrument and measures}

The method we use is the survey method. We collect the data through the self-administered questionnaire. The survey instrument of the current study addresses two major purposes. First is to analyze the relationship of different variables on the customer loyalty.

Second to collect information about the different characteristics of the respondents that can be used to understand the variation in different categories.

The survey instrument contains two sections. Section 1 includes different personal and 


\section{Macrothink}

demographic variables. This section will obtain the respondent's information about gender, age, income, education and status.

Section 2 includes the latent variables that are important in the current study. These variables include Customer Satisfaction, Customer Trust, Vendor Communication, Perceived Value, Perceived Quality, Relational Benefits, and Brand Credibility toward the Customer Loyalty.

The scale of this study was adopted by the previous literature and published studies.

Table 1:Scales of the Study

\begin{tabular}{|c|c|c|c|}
\hline No & Variable & Items & Reference \\
\hline 1 & $\begin{array}{l}\text { Customer } \\
\text { loyalty }\end{array}$ & $\begin{array}{l}\mathbf{1} \text { I use mobile from the Nokia } \\
\text { company I am evaluating because it } \\
\text { is the best choice for me. } \\
2 \text { I consider myself to be a loyal } \\
\text { patron of the manufacturer of Nokia } \\
\text { I am evaluating. } \\
\mathbf{3} \text { I am committed to the } \\
\text { manufacturer of Nokia I am } \\
\text { evaluating. } \\
\mathbf{4} \text { I intend to keep buying the } \\
\text { Mobile of the Nokia } \\
\mathbf{5} \text { I would not switch to a } \\
\text { competitor, even if I had a problem } \\
\text { with the company }\end{array}$ & HyungSeok Lee1 \\
\hline 2 & Customer Trust & $\begin{array}{l}\text { 1. I trust on this Company. } \\
\text { 2. I rely on this Company. } \\
\text { 3. This is an honest company. } \\
\text { 4. This company meets my } \\
\text { expectations. } \\
\text { 5. This company is safe. }\end{array}$ & $\begin{array}{l}\text { Metzger it al, (2008). Chanduhuri } \\
\text { and Holbrook,(2001) }\end{array}$ \\
\hline 3 & $\begin{array}{l}\text { Customer } \\
\text { Satisfaction }\end{array}$ & $\begin{array}{l}1 \text { Overall I am satisfied with specific } \\
\text { experience with the Nokia. }\end{array}$ & $\begin{array}{l}\text { Yue Pan a,n, SimonShengb, } 1 \text {, } \\
\text { FrankT.Xiec, } 2\end{array}$ \\
\hline
\end{tabular}




\begin{tabular}{|c|c|c|c|}
\hline & & $\begin{array}{l}2 \text { I am satisfied with my decision to } \\
\text { purchase from this Company. }\end{array}$ & \\
\hline 4 & $\begin{array}{l}\text { Percived } \\
\text { Quality }\end{array}$ & $\begin{array}{l}\text { 1. This brand is of high quality. } \\
\text { 2. It is likely that the brand is very } \\
\text { high quality. } \\
\text { 3. It is likely that Company provide } \\
\text { consistent quality. } \\
\text { 4. it is likely that the Compnay offer } \\
\text { excellent features in its mobile }\end{array}$ & Yoo et al (2000) \\
\hline 5 & $\begin{array}{l}\text { Brand } \\
\text { credibility }\end{array}$ & $\begin{array}{l}\text { 1. This Company has the ability to } \\
\text { deliver what it promises } \\
\text { 2. The Company's brands claims are } \\
\text { believable } \\
\text { 3. Over time, my experiences with } \\
\text { this brand have led me to expect it to } \\
\text { keep its promises, no more and no } \\
\text { less } \\
\text { 4. the company's brand has a name } \\
\text { you can trust }\end{array}$ & Jill Sweeneya,_, Joffre Swaitb \\
\hline 6 & $\begin{array}{l}\text { Vendor } \\
\text { Communication }\end{array}$ & $\begin{array}{l}\text { 1.The company respond to your } \\
\text { claims } \\
\text { 2.Do you think company consider } \\
\text { your feed backs while making } \\
\text { decision } \\
\text { 3.Do you have access to the top level } \\
\text { management }\end{array}$ & $\begin{array}{l}\text { Sumarto, } \\
\text { PrasetyoHadi } \\
\text { DewiKhrisna }\end{array}$ \\
\hline 7 & Perceived Value & $\begin{array}{l}\text { The prouduct itself is worthy } \\
\text { This brand is reasonably priced } \\
\text { This brand offers value for the }\end{array}$ & $\begin{array}{l}\text { AnberAbraheemShlash } \\
\text { Mohammad }\end{array}$ \\
\hline
\end{tabular}




\begin{tabular}{|l|l|l|l|}
\hline 8 & $\begin{array}{l}\text { money } \\
\text { Relational } \\
\text { benfits }\end{array}$ & $\begin{array}{l}\text { I use this company's product because } \\
\text { of its durability } \\
\text { I choose this company because it } \\
\text { provide economical product } \\
\text { I use this company's product because } \\
\text { it is easy to use }\end{array}$ & Po-Tsang Chen *, Hsin-Hui Hu \\
\hline
\end{tabular}

\subsection{Procedure}

The questionnaire was distributed among 150 respondents in Bahawalpur and Lodhran. These respondents were selected based on the criteria above mentioned. Before giving the questionnaire, the purpose of study and questions were explained to the respondents so they can easily fill the questionnaire with relevant responses. A total of 150 questionnaires were properly filled by the respondents and included in the future analysis. After collecting the completed questionnaires, these questionnaires were coded and entered in to SPSS sheet for further analysis.

\subsection{Reliability analysis}

Overall cronbach's alpha of customer loyalty questionnaire item were .798 that is more than acceptable and recommended value 0.50 by nunnally(1970) and .60 by moss et al.(1998) this shows that all the 27 items were reliable and valid to measure the opinions of consumers towards customer loyalty.

Table 2: Reliability of measurement instrument

\begin{tabular}{|l|l|l|}
\hline Scales & Items & Cronbach Alpha \\
\hline Customer loyalty & 5 & .798 \\
\hline Customer Trust & 4 & .851 \\
\hline Customer Satisfaction & 2 & .637 \\
\hline
\end{tabular}




\begin{tabular}{|l|l|l|}
\hline Macrothink & \multicolumn{1}{c|}{$\begin{array}{r}\text { Journal of Sociological Research } \\
\text { ISSN 1948-5468 } \\
\text { 2014, Vol. 5, No. 1 }\end{array}$} \\
\hline Perceived Quality & 3 & .548 \\
\hline Brand Credibility & 4 & .746 \\
\hline Vendor Communication & 3 & .575 \\
\hline Perceived Value & 3 & .726 \\
\hline Relational Benefits & 3 & .714 \\
\hline
\end{tabular}




\section{Results and Analysis}

\subsection{Profile of the respondents}

Personal and demographic information such as gender, age, income education level, status are presented in the following table.

\begin{tabular}{|c|c|c|c|}
\hline & Category & Frequency & Percentage \\
\hline \multicolumn{4}{|l|}{ variables } \\
\hline Gender & $\begin{array}{l}\text { Male } \\
\text { female }\end{array}$ & $\begin{array}{l}95 \\
55\end{array}$ & $\begin{array}{l}63.3 \\
36.7\end{array}$ \\
\hline Age & $\begin{array}{l}\text { 15-20 years } \\
20-25 \text { years } \\
25-30 \text { years } \\
30-35 \text { years } \\
35-40 \text { years } \\
\text { Above } 40 \text { years }\end{array}$ & $\begin{array}{c}71 \\
56 \\
16 \\
4 \\
2 \\
1 \\
1\end{array}$ & $\begin{array}{l}47.3 \\
37.3 \\
10.7 \\
2.7 \\
1.3 \\
.7\end{array}$ \\
\hline Income & $\begin{array}{l}\text { Below } 15000 \\
15000-25000 \\
25000-35000 \\
35000-45000 \\
45000-55000 \\
\text { Above } 55000 \\
\text { Total }\end{array}$ & $\begin{array}{l}76 \\
43 \\
14 \\
4 \\
4 \\
9 \\
150\end{array}$ & $\begin{array}{l}50.7 \\
28.7 \\
9.3 \\
2.7 \\
2.7 \\
6.0\end{array}$ \\
\hline Education & $\begin{array}{l}\text { Matriculation } \\
\text { Inter } \\
\text { Bachelor } \\
\text { Master } \\
\text { M Phil/MS } \\
\text { PHD } \\
\end{array}$ & $\begin{array}{l}29 \\
21 \\
59 \\
27 \\
13 \\
1 \\
\end{array}$ & $\begin{array}{l}19.3 \\
14.0 \\
39.3 \\
18.0 \\
8.7 \\
.7 \\
\end{array}$ \\
\hline status & $\begin{array}{l}\text { Student } \\
\text { Employed } \\
\text { Unemployed } \\
\text { Married } \\
\text { Single }\end{array}$ & $\begin{array}{l}102 \\
39 \\
7 \\
0 \\
2\end{array}$ & $\begin{array}{l}68.0 \\
26.0 \\
4.7 \\
0 \\
1.3\end{array}$ \\
\hline
\end{tabular}

Table 3: Profile of the Respondents 


\subsection{Hypothesis testing:}

\subsubsection{Customer Trust and Customer Loyalty}

According to the result of the study, the variable Customer trust has significant positive relationship with the Customer loyalty. Specifically, the Customer Trust has a significant positive relationship with $(\beta=.439)$ and $(\rho<.001)$ that means the customer trust contribute more than $40 \%$ to customer loyalty. Our result of the study validate the hypothesis $\mathrm{H} 1$,

\subsubsection{Customer Satisfaction, Customer loyalty and Customer Trust}

The regression result of the customer satisfaction also significant with $(\beta=.132)$ and $(\rho=.04)$. It means that Customer Satisfaction contributes 13 percent in the Customer loyalty. The regression results of the study confirm the significant positive relationship between customer satisfaction and Customer Trust with $(\beta=.272)$ and $(\mathrm{p}=<.01)$. The result validates the hypothesis $\mathrm{H} 3$ and $\mathrm{H} 2$.

\subsubsection{Perceived Value and Customer Satisfaction}

While considering the significance between perceived value and customer loyalty, the results of the current study shows no significant relationship between these two variables with $(\beta=.077)$ and $(\rho>.05)$. According to the results, there is no significant relationship between perceived value and Customer Satisfaction with $(\beta=.077)$ and $(\rho>.05)$. Based on these results, we reject $\mathrm{H} 4$ and conclude that the study did not find significant relationship of perceived value with the Customer Satisfaction

\subsubsection{Relational Benefits, Customer Satisfaction and Perceived Value}

The influence of the relational Benefits on the Customer Satisfaction is also positive with significant $(\beta=.359)$ and $(p<.001)$. Relational benefits have positive relation toward the perceived value with significant $(\beta .625)$ and $(\rho<.001)$. These results of the Study validate the Hypothesis H5 and H6.

\subsubsection{Brand Credibility and Customer Trust}

The Brand Credibility has the positive relation with the Customer trust with significant $(\beta=.230)$ and $(\mathrm{p}=.013)$. It validate the Hypothesis $\mathrm{H} 7$

\subsubsection{Perceived Quality, Customer Satisfaction and Customer Trust}

Our results of the study show the positive impact of the Perceived Quality on the Customer Satisfaction with signification $(\beta=.404)$ and $(\mathrm{p}<.001)$. Perceived Quality positively affects the Customer Trust with significant $(\beta=.208)$ and (p.021). These results show the validation of the $\mathrm{H} 8$ and $\mathrm{H} 9$

\subsubsection{Vendor Communication and customer loyalty}

Results also show the positive relation of the Vendor Communication toward the customer loyalty with significant $(\beta=.197)$ and $(\rho<.01)$. The results validate the hypothesis H10 
Table5: Regression Results

\begin{tabular}{|c|c|c|c|c|c|c|}
\hline Hypothesis & Model variables & $\begin{array}{l}\text { Estimate } \\
\text { S.E }\end{array}$ & S.R. & C.R & $\mathrm{P}$ & Results \\
\hline $\mathrm{H} 1$ & Cus-Loy $\longleftarrow$ Cus-Trst & .439 & .075 & 5.496 & .001 & Supported \\
\hline $\mathrm{H} 2$ & Cus-TrstCus-Sat & .272 & .088 & 3.060 & .01 & Supported \\
\hline H3 & $\begin{array}{l}\text { Cus-Loy } \\
\text { Cus-Sat }\end{array}$ & .132 & .071 & 1.709 & .04 & \\
\hline $\mathrm{H} 4$ & $\begin{array}{l}\text { Cus-sat } \\
\text { Per-Vlu }\end{array}$ & .077 & .086 & .972 & .333 & $\begin{array}{l}\text { Not } \\
\text { Supported }\end{array}$ \\
\hline $\begin{array}{l}\mathrm{H} 5 \\
\mathrm{H} 6\end{array}$ & $\begin{array}{l}\text { Cus-sat } \\
\text { Rel-Ben } \\
\text { Per-vluRet-Ben }\end{array}$ & $\begin{array}{l}.359 \\
.625\end{array}$ & $\begin{array}{l}.077 \\
.059\end{array}$ & $\begin{array}{l}4.628 \\
9.697\end{array}$ & $\begin{array}{l}.001 \\
.001\end{array}$ & Supported \\
\hline $\mathrm{H} 7$ & Cus-trstBrnd-Cre & .230 & .114 & 2.507 & .013 & Supported \\
\hline $\begin{array}{l}\mathrm{H} 8 \\
\mathrm{H} 9\end{array}$ & $\begin{array}{l}\text { Cus-sat } \longleftarrow \\
\text { Per-Qulty } \\
\text { Cus-trstPer-Qutlty }\end{array}$ & $\begin{array}{l}.404 \\
.208\end{array}$ & $\begin{array}{l}.097 \\
.124\end{array}$ & $\begin{array}{l}5.864 \\
2.333\end{array}$ & $\begin{array}{l}.001 \\
.021\end{array}$ & Supported \\
\hline H10 & Cus-loyVen-Com & .197 & .076 & 2.637 & .01 & Supported \\
\hline
\end{tabular}

\section{Discussion}

This study attempts to investigate the factors affecting customer loyalty of Nokia mobiles in Pakistan. We studied the effects of Customer Trust, Customer Satisfaction, Vendor Communication, Perceived Value, Perceived Quality, Relational Benefits, and Brand Credibility on Customer Loyalty. The prime object of the research is to study the customer loyalty.

In this research, we study how the customer can be loyal with a company or an organization and what are the factors which influence the customer to purchase one product again and again or purchase anything from one organization repeatedly. We know that the competition in the market is so much high and customer loyalty is the basic thing for the companies to survive in the global market. Customer loyalty always remains on the focus of the companies because of retaining their customer with them is one of the most important factors. If companies succeed to create loyalty, it will help them to reduce their cost and increase their sales and profit, the reason is that attracting new customer much costly. There are a lot of 
researches on the customer loyalty but our current study formulates that how Customer Loyalty is created and how Customer Trust, Vendor Communication, and Customer Satisfaction affect the Customer Loyalty and what are the factors which influence the Customer Trust and Satisfaction toward the Customer Loyalty. Now we will discuss these results in the following section.

First, we define and discuss our variables and their relationships. Customer trust is one of these variables which influence the customer loyalty. Previous research proves that customer trust has the positive influence on the Customer loyalty. According to Morgan and Hunt (1994), relationships are the series of transactions which encourage the understanding of shared relationship through trust and commitment. If trust and commitment are higher than it will lead to higher customer retention, when customer retention will be increased then firm's profitability will also be increased. Findings of the current study are that the customer trust has a significant positive relation to the customer loyalty with $(\beta=.439)$ and $(\rho<.001)$. It means that customer trust has greater importance to make the loyalty of the customer.

Second, Customer satisfaction has great importance for the customer loyalty and it also has positive impact on the customer trust. Previous studies explained that there is a positive relation between customer satisfaction and customer loyalty. When customer transacts with the supplier and purchases any product, then he evaluates that his expectations are meeting or not with the use of that brand. If it is according to his expectations then he will give high rate to the brand and will be loyal with it (Johnson \& Fornell,1991). Satisfaction means meeting the expectations of the customer, when companies meet their expectations they create the loyalty of the customer. Results show the positive significant relationship between the customer satisfaction and the customer loyalty with $(\beta=.132)$ and $(\rho=.04)$. In our current study, customer satisfaction influences the customer trust and customer loyalty. If company is giving the same thing which it is promising then it means that they are creating trust. When company promises something to the customer then customer expect that they will fulfill their promise which company has made and when company fulfills its promises then customer feels himself satisfied and this feeling of satisfaction force the customer to purchase the product again and again. Results of our study show the significant positive influence of the customer satisfaction with the customer trust with $(\beta=.272)$ and $(\mathrm{p}=<.01)$.

Thirdly, our result shows that the perceived value has no significant relation with the customer loyalty with $(\beta=.077)$ and $(\rho>.05)$. Perceived value is basically the cost and benefit analysis,(i.e., if I think that I am giving 200 rupees and receiving the benefit equal to 200 rupees, it means that the product has the value of 200 and this thing give the satisfaction to customer, that he recover the cost of the product.

Reason of rejection and insignificance is that we collected most of the data from the youngsters and our major population of the study depends on the youngster (i.e., 95\%). These youngsters make a great value before purchasing the Nokia mobile. Moreover, they are from backward areas of Pakistan i.e., Lodhran and Bahawalpur. Their purchasing power is not high. They just purchase mobile with the value created by other influencer but when they experience the product they are dissatisfied because their expected perceived value or benefit 
is so much greater than the actual product performance. The other reason is that our study does not specify a single product. There is a range of Nokia mobiles and we do not specifically target one model. We are generally analyzing the loyalty of Nokia customer. Some models of Nokia are satisfying the customer according to their perceived value e.g. Nokia C3, but some are not doing according to their expected value which is created by the company e.g. Nokia Lumia, due $t$ this the customer became dissatisfied. People purchase Lumia because of the prestigious name of Nokia and also of their high promotional activities. But they are dissatisfied with Lumia because of its features. It is useless without internet. People get bored without internet access in Mobile. So, in this situation perceived value negatively affects the customer satisfaction. So, these are the reasons which create confusion and insignificance in our result, because some of the company's models meet the customer expectation and some do not.

Fourth, results of our study show the positive influence of the relational benefits on the customer satisfaction and the perceived value. Relational benefits of the product are those benefits which are associated with the product. These benefits can be the social benefits, economical benefits, usage benefits, religious benefits etc. The influence of the relational benefits on the customer satisfaction are also positive with $(\beta=.359)$ and $(\mathrm{p}<.001)$. The reason is that, some people are conscious about the price of the product, they feel pleasant when they use economical product. Some people are not so much literate in those areas from where we collect the data, so if product is easy to use then it meets the requirements of the people and as we discuss meeting the requirements and the expectations of the customer make them satisfied. Our study also finds the positive relation of the relation benefits with the perceived value with $(\beta .625)$ and $(\rho<.001)$. Relational benefits create a value in the mind of the customer.

Our study also shows the positive effects of the brand credibility on the customer trust. Previous studies reveals, (Kotler and Keller's)brand is a notion, brand is an indicator to measure the quality, so the brand has the ability to satisfy the demand of the customers and build their trust and force the customer to repurchase the one product again and again. The Brand Credibility has the positive relation with the Customer trust with $(\beta=.230)$ and $(\mathrm{p}=.013)$. Nokia is a trust worthy and a credible name, when we listen something about Nokia, it automatically creates a trust in our minds. We think that they will deliver what they promise.

We also study the impact of the perceived quality on the customer satisfaction and the customer trust. Results show that perceived quality positively affects the customer satisfaction and customer trust. Results of the findings show the positive impact of the perceived quality on the customer satisfaction with $(\beta=.404)$ and $(p<.001)$. Perceived quality positively affects the customer trust with $(\beta=.208)$ and (p.021).Perceived quality is the experience about the product which customer get after using the product and this positive experience creates the customer satisfaction and customer trust, because customer realize that company meets his expectations and delivers the value what it promises.

In our study, we also explore the relationship of the vendor communication to the customer 
loyalty. As we know, customer loyalty is the repurchasing behavior of the customer and vendor communication is the factor which influences the loyalty of the customer. The speed of vendor responding to customer complaints really affects the increased sales of online vendor. Vendor who does not give good response to customer sooner or later will be left by customer. This finding corresponds with Gefen and Straub (2004) on how customer-vendor communication has influenced the purchase intention which has been an indicator of loyalty construct. Our results of study show the positive relation of the customer with $(\beta=.197)$ and $(\rho<.01)$.

\section{Conclusion}

In this paper, we have presented an empirical study to measure the loyalty of the customer toward the Nokia mobile in Pakistan. For the purpose of this research, we found out the variables which affect the loyalty of the customer. These variables are customer trust, customer satisfaction, and vendor communication. These variables directly influence the loyalty of the Nokia customer and the factors which influence customer trust are perceived quality, brand credibility and satisfaction of the customer. Like this, satisfaction is influenced by the perceived value, relational benefits, and perceived quality. Perceived value is influenced by the relational benefits. To test the impact of the variables, we use survey technique to collect the data and analyze it with the help of the SPSS. The findings of our research show that all the variables have positive significant relation $\rho<.05$ with each other except perceived value on satisfaction. It has insignificant relation with the customer satisfaction with $\rho>$.05. It means that if we want to create the loyalty of customer then we have to establish the trust of the customer with the companyand make him satisfied with the company and maintains continuous contact with the customer.We can develop trust with providing quality and credibility or trust worthy product to the customer, Satisfaction can be given to the customer through the relational benefits and also the quality of the product. While giving them satisfaction, we should be conscious about the perceived value that it should not be higher than the actual product performance otherwise customer will be dissatisfied. In this way, organization can maintain long-term relation with their customer.

\section{Implications of research}

In our research our focus was on the customer loyalty. With this research, we find that how much customer loyalty is important for the businesses. Businesses always seek the loyalty of their customer but the major question is that what are the parameters with which loyalty can be created. Our research gives the answers of this question. In our research, we check the relationships of the customer loyalty with other variable which form loyalty. These factors are the customer trust, customer satisfaction, vendor communication, perceived value, relational benefits, perceived quality, and brand credibility. This particular result has major implications in those companies which are not achieving their targets and for those which are on the initial business stage. If companies want to increase their sales and profits then our research helps them to get idea about the repurchasing behavior of the customer.

If we discuss the retail business in Pakistan, our research is also beneficial for them. In Pakistan, shopkeeper and retailer always try to seek high profit, they have lack of sense to 
create long-term relation with the customer and that is the reason Pakistan faces difficulties in business sector. Our research also helps them to get understanding about the local customer nature that what he expect from you. If you are meeting his requirements then it means you are getting actual profit which is long lasting.

\section{Limitation and future research}

In our research, we study that how customer loyalty can be created. There are some limitations of our research. First; our sample size is too small. We collect the data from the 150 respondents. We know that as our sample size is larger our research's result will be more reliable. Second we collect the data from the two cities of Pakistan so it does not explain the loyalty of Nokia mobile customer all over the Pakistan. Other limitations of our research are that we get the Nokia mobile in general. We do not specify the single or particular model of Nokia. So, all of these limitations prevail in our research. We will recommend that future research which will be about the loyalty of the customer should be clean from all of these things.

\section{Reference}

[1] Bitner, M. J., \&Hubbert, A. R. (1994). Encounter satisfaction versus overall satisfactionversus quality. In R. T. Rust, \& R. L. Oliver (Eds.), Service quality: New directions intheory and practice (pp. 72-94). Thousand Oaks, CA: Sage.

[2] Gwinner, K.P., Gremler, D.D., Bitner, M.J., 1998. Relational benefits in services industries: the customer's perspective. Journal of the Academy of Marketing Science 26, 101-114.

[3] Hennig-Thurau, T., Gwinner, K.P., Gremler, D.D., 2002. Understanding relationship marketing outcomes: an integration of relational benefits and relationship quality. Journal of Service Research 4, 230-247.

[4] Flint, D. J. (2004). Strategic marketing in global supply chains: Four challenges. Industrial Marketing Management, 33(1), 45-50.

[5] Oliver, R. L. (1980). A cognitive model of the antecedents and consequences of satisfaction decisions. Journal of Marketing Research, 17(4), 460-469 
[6] Oliver, R. L. (1999). Whence consumer loyalty? Journal of Marketing, 63(4), 33-44.

[7] Rust, R. T., \& Oliver, R. L. (1994). Service quality: New directions in theory and practice. Thousand Oaks, CA: Sage.

[8] Bitner, M.J., 1995. Building service relationships: it's all about promises. Journal ofthe Academy of Marketing Science 23 (Fall), 246-251.

[9] Berry, L.L., 1995. Relationship marketing of service: growing interest, emerging perspectives. Journal of the Academy of Marketing Science 23 (4), 236-245.

[10] Barlow, R.G., 1992. Relationship marketing: the ultimate in customer services. Retail Control March 29-37

[11] Crosby, L.A., 1991. Building and maintaining quality in the service relationship.

[12] Gro“ nroos, C., 1994. From marketing mix to relationship marketing: towards a paradigm shift in marketing. Management Decision 32 (2), 4-20.

[13] Morgan, R. M., \& Hunt, S. D. (1994). The commitment-trust theory of relationshipmarketing.Journal of Marketing, 58(3), 20-38.

[14]Czepiel, J.A., 1990. Service encounters and service relationships: implications for research. Journal of Business Research 20 (1), 13-21.

[15]Parasuraman,A.,Berry,L.L.,Zeithaml,V.A.,1988.SERVQUAL:amultiple-itemscale for measuringconsumerperceptionsofservicequality.JournalofRetailing64 (1), 12-40.

[16] Slater, S. F., \&Narver, J. C. (2000). Intelligence generation and superior customer value.Journal of the Academy of Marketing Science, 28(1), 120-127

[17] Woodruff, R.B.,1997.Customervalue:thenextsourceofcompetitiveadvantage. Journal oftheAcademyofMarketingScience25(2),139-164. Y. 


\section{Macrothink}

[18]Flint, D. J., Woodruff, R. B., \&Gardial, S. F. (2002). Exploring the phenomenon of customers' desired value change in a business-to-business context. Journal of Marketing, 66(4), 102-117.

[19] Akhter, W., Abbasi, A.S., Ali, L. \&Afzal, H. (2011). Factors affecting customer loyalty in Pakistan.African Journal of Business Management, 5(4), 1167-1174.

[20]Reichheld, F. F. (1996). The Loyalty Effect: the Hidden Force behind Growth, Profits, and Lasting Value. Boston,

MA: Harvard Business School Press.

[21]Fornell, C. (1992). A national customer satisfaction barometer: The Swedish experience. Journal of Marketing,56(1), 6-12. http://dx.doi.org/10.2307/1252129

[22] Aydin, S., Ozer, G., \&Arasil O. (2005). Customer loyalty and the effect of switching costs as a moderator variable: A case in the Turkish mobile phone market. Marketing Intelligence \& Planning,23(1), 89-103

[23] Matt Hasan (2001), "The importance of customer retention ", Proceedings of the Marketing in a Global Economy Conference, Buenos Aires, pp. 215-224.

[24]Morgan, R.M., Hunt, S.D., 1994. The commitment-trust theory of relationship marketing. Journal of Marketing 58 (July), 20-38.

[25]Anderson, E., \&Weitz, B. (1989). Determinants of continuity in conventional industrialchannel dyads.Marketing Science, 8(3), 10-23.

[26]Berry, L. L. (1995). Relationship marketing of services: Growing interest, emergingperspectives. Journal of the Academy of Marketing Science, 23(4), 236-245.

[27]Crosby, L. A., Evans, K. R.,\&Cowles, D. (1990). Relationship quality in services selling: An interpersonal influence perspective. Journal of Marketing, 54(3), 68-81.

[28]Hennig-Thurau, T., \& Klee, A. (1997). The impact of customer satisfaction and 


\section{Macrothink}

relationship quality on customer retention: A critical reassessment and model development. Psychology and Marketing, 14(8), 737-764.

[29] Yousafzai, S.Y., Pallister, J.G., and Foxall, G.R. (2003), "A proposed model of e-trust for electronic banking", Technovation, Vol. 23 No. 11, pp. 847-860.

[30] Mayer, R.C., Davis, J.H. and Schoorman, F.D. (1995). "An integratif model of organizational trust", Academy of Management Review, Vol. 30 No. 3, pp. 709-734

[31]Ndubisi, O.N. (2007). Relationship Marketing and Customer Loyalty, Marketing Intelligence \& Planning, 25(1), 98-106.

[32] Spreng, R. A., MacKenzie, S. B., \&Olshavski, R. W. (1996). A reexamination of the determinants of consumer satisfaction. Journal of Marketing, 60(3), 15-32.

[33] Rauyruen, P., \& Miller, K. E. (2007). Relationship quality as a predictor of B2B customer loyalty.Journal of Business Research, 60(1), 21-31

[34] Roberts, K., Varki, S., \&Brodie, R. (2003). Measuring the quality of relationships in consumer services: An empirical study.European Journal of Marketing, 37(1/2),169-196.

[35]Hennig-Thurau, T., \& Klee, A. (1997). The impact of customer satisfaction and relationship quality on customer retention: A critical reassessment and model development. Psychology and Marketing, 14(8), 737-764.

[36]Dwyer, R. F., \& Oh, S. (1987). Output sector munificence effects on the internal political economy of marketing channels. Journal of Marketing Research, 24(4), $347-358$.

[37] Jaworski, B. J., \&Kohli, A. K. (1993). Market orientation: Antecedents and consequences Journal of Marketing, 57(3), 53-70 
[38] Ranaweera, C. and Prabhu, J. (2003), "the influence of satisfaction, trust and switching barriers on customer retention in a continuous purchasing setting", International journal of service Industry Mangement, VO1 14 No. 4, pp. 374-395

[39]Hart, C. and Johnson, M (1999), "Growing the trust relationship", journal of marketing Management, Vol. 8 No.1, pp. 8-19

[40] Stewart,K.,(1998),“An exploration of custome exit in retail banking. International journal of bank marketing Vol16,pp.6-14

[41] Well A and Morrison qualitative discussion of customer worry and normal obsession a comparative study Behavior research and therapy 32 867-870

[42]Holbrook, M. B. (1994). The nature of customer's value: An axiology of service in consumption experience. In R. T. Rust,\& R. L. Oliver (Eds.), Service quality: New

directions in theory and practice (pp. 21-71). Thousand Oaks, CA: Sage Publi-

cations.

[43]Peterson, R. (1995). Relationship marketing and consumer. Journal of Academy of Marketing Science, 23(4), 278-281.doi:10.1177/009207039502300407, http://dx.doi.org/10.1177/009207039502300407

[44]Ganesan, Shankar (1994). Determinants of long term orientation in buyer-seller relationship.Journal of Marketing, 58,1-19. doi:10.2307/1252265, http://dx.doi.org/10.2307/1252265

Rizwan, M., Ahmad, W., Tahir, S., Ali, S., Naz, A., Ain, Q. \& Peerzada, F. (2013) The Impact of Brand Trust, Brand Attachment and Brand Commitment on Brand Loyalty, International Journal of Research in Commerce, Economics and Management, 3(3), 129-141

[45] Kotler\& Keller 2008: Marketing Management (13th Edition) Philip Kotler Kevin Keller Publisher:Prentice Hall; 13 edition (March 6, 2008)

[46] Guenzi, P. and Pelloni, O. (2004) The Impact of Interpersonal Relationships on Customer Satisfaction and loyalty to the Service Provider, International Journal of Service Industry 


\section{Macrothink}

Journal of Sociological Research

ISSN 1948-5468

2014, Vol. 5, No. 1

Management, 15(4), 365-84parg, S.G., N.B. Jones and J. van Staden. 2002. Artificial seed fromPinuspatulasomatic embryos. S. Afr. J. Bot. 68:234-238.

[47]

Rensburg, RS \& M Cant 2003. Public Relations: South African Perspectives SoutAfrica: Heinemann.

Rezai, Mahmoud (2009) "Effects of interpersonal communication on

satisfaction and loyalty of customers (parents) in a non-profit schools of high school in Tehran", MS Thesis, Tehran University

[49]

Heidarzadeh, KambizHosseiniFirouzabadi, (2006) study of

interpersonal

communication and its impact on customer satisfaction and loyalty to the service provider, Journal of Marketing Management, Islamic Azad University,

Tehran Science and Research.

[50]

Dwyer, F Robert; Paul H Schurr; Sejo Oh (1987), "Developing Buyer

Seller

Relationships, Journal of Marketing. 51(Apr), 2, 11-27.

[51]Rauyruen, P., \& Miller, K. E. (2007). Relationship quality as a predictor of

B2B customer loyalty. Journal of Business Research, 60(1), 21-31

[52] Oliver, R.L., Rust, R., Varki, S., 1997. Customer delight: foundations,

findings and managerial insight. Journal of Retailing 73, 311-336. 